\title{
Cucumber mosaic virus infection of kava (Piper methysticum) and implications for cultural control of kava dieback disease
}

\author{
R. I. Davis ${ }^{\mathrm{A}, \mathrm{D}}$, M. F. Lomavatu-Fong ${ }^{\mathrm{B}}$, L. A. McMichael ${ }^{\mathrm{C}}$, T. K. Ruabete , $^{\mathrm{A}}$, \\ S. Kumar ${ }^{\mathrm{A}}$ and U. Turaganivalu ${ }^{\mathrm{B}}$ \\ ${ }^{A}$ Land Resources Division, Secretariat of Pacific Community, Suva, Fiji Islands. \\ ${ }^{B}$ Ministry of Agriculture, Sugar and Land Resettlement, Koronivia Research Station, Nausori, Fiji Islands. \\ ${ }^{\mathrm{C}}$ Department of Primary Industries and Fisheries, AFFS, Horticulture, 80 Meiers Road, Indooroopilly, Qld 4068, Australia. \\ ${ }^{\mathrm{D}}$ Corresponding author. Email: RichardD@spc.int
}

\begin{abstract}
Cucumber mosaic virus (CMV) was found by reverse transcription polymerase chain reaction (RT-PCR) to be not fully systemic in naturally infected kava (Piper methysticum) plants in Fiji. Twenty-six of 48 samples (54\%) from various tissues of three recently infected plants were CMV-positive compared with 7/51 samples (14\%) from three long-term infections (plants affected by dieback for more than 1 year). The virus was also found to have a limited ability to move into newly formed stems. CMV was detected in only $2 / 23$ samples taken from re-growth stems arising from known CMV infected/dieback affected plants. Mechanical inoculation experiments conducted in Fiji indicate that the known kava intercrop plants banana (Musa spp.), pineapple (Ananas comosus), peanut (Arachis hypogaea) and the common weed Mikania micrantha are potential hosts for a dieback-causing strain of CMV. It was not possible to transmit the virus mechanically to the common kava intercrop plants taro (Colocasia esculenta), Xanthosoma sp., sweet potato (Ipomoea batatas), yam (Dioscorea alata), papaya (Carica papaya) or the weed Momordica charantia. Implications of the results of this research on a possible integrated disease management strategy are discussed.
\end{abstract}

\section{Introduction}

Kava (Piper methysticum) is a crop grown in many Pacific Island countries and territories and is used to prepare an intoxicating, mildly narcotic beverage of great cultural and ceremonial importance (Lebot et al. 1992). The drink is an emulsion of active ingredients prepared from the roots and stem base of kava plants and induces relaxation and sleepiness (Gatty 1956; Singh 1992). Kava is a perennial shrub which can only be propagated vegetatively. Each plant consists of a number of slightly succulent stems which arise from the base of the plant and can reach a height of $2-3 \mathrm{~m}$ by the time of harvest (usually after $3-5$ years).

Kava is of great economic significance in the Pacific region. Financial returns in the Fiji Islands (Kumar et al. 1998), Tonga and Vanuatu (Davis and Brown 1999) exceed that of most alternative crops. There is also a huge potential export market for the crop (Kumar et al. 1998), the germplasm of which originates in the south-east Pacific (Lebot et al. 1992).

The greatest constraint to kava production is a dieback disease first reported in Fiji in 1932 (Parham 1935), and which is also a problem in Tonga, Samoa and Vanuatu (Davis et al. 1996; Davis and Brown 1999). In Fiji today, losses from kava dieback disease regularly reach $40 \%$ and entire production regions have been devastated (Ratu J. Nawalowalo, Chair, Fiji Kava Council, personal communication). Symptoms of the disease are highly distinctive. Most characteristic is a rapidly spreading black soft rot of stem tissue. Stem rot is usually preceded by the appearance (3-4 weeks before) of virus-like symptoms on leaves induced by Cucumber mosaic virus (CMV) (Davis et al. 1996). Kava plants are not immediately killed by dieback. Usually only some stems are affected at any one time, and regrowth occurs continuously. In natural epidemics, cycles of dieback and regrowth have been reported from both Fiji (Parham 1935) and Tonga (Davis and Brown 1996). A causal relationship between kava dieback and CMV infection has been clearly demonstrated using enzyme linked immunosorbent assay (ELISA) testing (Davis et al. 1996). First, the virus was found consistently associated with kava dieback in Tonga, Fiji, Vanuatu and Samoa. Then an artificial inoculation experiment was conducted in a controlled environment glasshouse in Tonga after steps were taken to address the issues of host genetic or other variability, and possible co-infection with other viruses. CMV reproduced field symptoms of dieback and caused death or debilitating necrosis in all inoculated plants, whereas 
genetically identical control plants remained dieback-free. However, it was speculated by Davis et al. (1996) that CMV may interact with other unknown biotic or abiotic factors to induce dieback. This was because unexplained variability in host plant reaction was observed in the field between two different years, and the pathogenicity testing was unable to guarantee absence of all possible interacting factors.

As infection with CMV is essential for dieback development in kava plants, measures that reduce CMV spread through kava plantings should reduce disease impact. Timely removal of infected plants (rogueing) is a well-known plant virus disease control strategy, employed to reduce spread of Plum pox virus in Prunus spp. orchards (Kegler and Hartmann 1998), Citrus tristeza virus in citrus orchards (Garnsey et al. 1998), and Fiji disease virus in sugarcane (Egan et al. 1989). Davis and Brown (1996) demonstrated significant expansion of CMV infection foci within kava plantings, implying the likely effectiveness of rogueing. Subsequently, removal of entire plants was recommended to kava growers (Davis 1999; Anon. 2003). However, kava growers are unwilling to destroy plants, as each is of high monetary value and it is common knowledge that new growth follows stem rot.

There is some evidence suggesting that CMV is not fully systemic in kava plants. Naturally infected plants in Tonga were found to have an erratic and uneven distribution of CMV (Davis and Brown 1996). In the field, new growth is often free of virus-like leaf symptoms (R. Davis, unpublished data). If CMV is not fully systemic in infected kava plants, diseased stem removal (as opposed to entire plant destruction) may be an effective cultural control measure, more acceptable to growers.

In recent years, highly sensitive CMV detection techniques have been developed using reverse transcription polymerase chain reaction or RT-PCR (Bariana et al. 1994; Singh et al. 1995; Sharman et al. 2000). ELISA has been shown to be a relatively crude CMV detection method compared with PCR (Hu et al. 1995) and it may be that the virus was present throughout the plants studied in Tonga in the early 1990s, but only at a titre high enough for ELISA detection in certain plant parts. The first part of the study reported here is an intensive re-examination, using RT-PCR, of the CMV distribution in a small number of large multistemmed kava plants infected with CMV at two locations. Many samples were taken at one time from a few plants at only two locations because it is known from artificial inoculation experiments that host reaction to CMV varies little from plant to plant in a given situation, but variability in the field can be great when environmental or other conditions change (Davis et al. 1996).

As CMV is a non-persistent virus, intercropping with nonCMV hosts should greatly reduce rates of plant to plant spread in kava plots. Kava is usually inter-planted with a range of other Pacific Island crops in the early stages of growth.
Amongst these, banana (Musa sp.), and many cucurbit and solanaceous crops are well known hosts of CMV (CABI 2002). In addition, pineapple (Ananas comosus), sweet potato (Ipomoea batatas), papaya (Carica papaya) and possibly taro ('Colocasia sp.') are included as hosts of CMV in the listing of Douine et al. (1979). Other known CMV hosts include the common kava intercrop, yam (Dioscorea alata) (Brunt et al. 1989) and peanut (Arachis hypogaea) (Frison et al. 1990), which is an occasional, but recommended (Anon. 2001), intercrop. CMV exists as a large number of different strains that cover significant genetic divergence (Roossinck 2001) and CMV strain-host specificity is known to exist (Bos and Maat 1974). It is not known if kava dieback-causing strains of CMV are restricted in their host range or are capable of infecting many other CMV host species, including those usually grown together with kava. The second part of the study reported here is an initial investigation into the CMV host status of these intercrops, plus two weed species common in Fiji.

\section{Methods}

\section{Kava material analysed in CMV intra plant distribution study}

Six individual kava plants were selected because they were showing disease symptoms of the right stage for study. They were growing at the Fiji Ministry of Agriculture, Sugar and Land Resettlement (MASLR) Naduruloulou and Doboilevu Research Stations (both in the east of Viti Levu Island). At both locations, kava dieback had been an ongoing problem for several years and presence of CMV confirmed by serological tests (R. Davis, unpublished data). Three plants (LTI1, LTI2, LTI3) were chosen as good examples of long-term CMV infection and ongoing dieback disease. These plants (one cv. Yaqona Matanitobua (LTI1), two cv. Yaqona Loa (LTI2,3) were $\sim 5$ years old and on each plant, dieback symptoms had been seen periodically for more than 1 year (M. Tanapa, Technical Officer, Agronomy, MASLR, personal communication) and there was evidence of earlier death and rot back to the stem base of at least ten stems. The remaining three plants (NI1, NI2, NI3) were selected as examples of apparently new infections. Two [one cv. Yaqona Mama (NI1), one cv. Yaqona Dokobana (NI2)] were 13 months old, growing in containers $\left(0.3 \mathrm{~m}^{3}\right.$ in volume) adjacent to infected field plots. The third (cv. Yaqona Loa) was a 10-month-old, field-grown plant. They were considered to be new infections because they were showing typical CMV-like yellow-on-green mosaic symptoms on one or more young leaves, but no advanced dieback-like stem rot symptoms. A mixture of different cultivars was used in this study because the plants were chosen primarily on the basis of stage of disease development. It is known from field trials and other studies that there are no significant differences among the cultivars grown in Fiji in dieback disease susceptibility (R. Davis, T. Ruabete and J. Brown, unpublished data). Completely symptomless control plants were selected from field sites as available. One was a 3 year old cv. Honolulu growing in the field at Naqali, south east Viti Levu, a location where occasional kava dieback epidemics have been known for many years (R. Davis, T. Ruabete and J. Brown, unpublished data). The other two (one cv. Honolulu, one cv. Yaqona Loa) were 1-year-old container-grown plants established from cuttings taken from symptomless stems collected on the Island of Vanua Levu.

From each kava dieback-affected plant, up to ten leaf samples (one leaf per stem depending on number of stems present) were collected. Up to five of these were leaves showing typical CMV-like mosaic symptoms and the remainder were from stems showing no leaf symptoms. As it is 
known that virus levels in stems bearing symptomatic leaves are high (Davis and Brown 1996), other tissues sampled were those apparently not showing outward signs of CMV infection, to determine if the virus had moved from stems with leaf symptoms into other parts of the plant. From each plant, these were stem tissue from three stems with asymptomatic leaves and three random samples from the stem base and root system. Symptomless control plants were sampled in a similar way except that only five leaf samples were taken.

\section{Kava material analysed in regrowth CMV infection study}

To determine the ability of CMV to move into newly produced kava stems, a number of young stems $(<20 \mathrm{~cm}$ in length) were selected for analysis. Each had grown from the stem base of plants at some time after they were known by ELISA or RT-PCR testing to be CMV infected. Ten new stems from NI1 and six from NI2 were removed 3 months after those plants were sampled for RT-PCR testing. A further seven stems were sampled from two field grown cv. Yaqona Loa plants that had tested positive by DAS-ELISA 4 and 5 months previously. Some older stems on NI1 and NI2 were still showing dieback symptoms when re-sampled. The CMV-positive stems on the Yaqona Loa had rotted back completely and all new growth appeared symptomless. Leaf and stem tissue samples were taken for RT-PCR testing from each stem.

\section{Virus detection by RT-PCR}

Plant tissue samples in the intra-plant distribution study were tested twice for presence of CMV. First, by RT-PCR following an RNA extraction procedure from leaf tissue, and then by an immunocapture (IC) RT-PCR analysis using macerated leaf tissue. In the first, RNA was extracted using a slight modification of the 'leaf soak' method of Thomson and Dietzgen (1995). The modification was an increase in the amount of material sampled to ten 2-mm-square pieces of plant tissue, incubated in a proportionally increased quantity of template preparation medium $(300 \mu \mathrm{L})$. This was done to increase the chance of detecting CMV if distribution was erratic. The IC RT-PCR method used was a slight modification of the CMV detection method described by Sharman et al. (2000). The differences were that ten 2-mm-squares of plant tissue were ground in $1 \mathrm{~mL}$ 'common extraction buffer (CEB)' and PCR tubes were coated with $2 \mu \mathrm{g} / \mathrm{mL}$ of a compound CMV antibody mixture (Agdia Inc., Elkhart, IN, USA). This detects a wide range of strains of CMV in both subgroups I and II and variation amongst dieback-causing strains of CMV was suspected. The 2-mm squares of tissue were selected from symptomatic areas, if present, and randomly if no CMV-like symptoms were seen. In most cases, the amount of tissue taken amounted to $<10 \%$ of the total sample. RT-PCR was carried out using CMV-specific primers (Bariana et al. 1994) and the Titan One-step RT-PCR System (Roche) according to manufacturer's instructions. RT-PCR competency of leaf, stem, stem base and root 'leaf soak' extracts was ascertained by repeating RT-PCR of a small number of extracts after adding an additional $1 \mu \mathrm{L}$ of known positive leaf soak extract from a CMV-positive leaf. Samples analysed in the later regrowth study and also the symptomless control plants were tested by IC RT-PCR only. CMV-free leaf tissue (sourced from meristem tip tissue culture plants grown in an aphid proof screen house) and extract preparations with no plant material included served as negative controls in each RT-PCR reaction. Expected amplification products were $500 \mathrm{bp}$ in size and were separated by $1 \%$ agarose gel electrophoresis, stained with ethidium bromide and visualised by UV illumination.

\section{Virus detection by ELISA}

DAS-ELISA tests were also conducted using compound direct ELISA reagent sets (Agdia Inc. Elkhart, IN, USA). Samples were considered positive when mean absorbance values (at $405 \mathrm{~nm}$ ) exceeded three times the mean of suitable non-infected controls of each plant species that were included on each microtitre test plate. Positive controls used in each ELISA tests were commercial (Agdia) products and known CMV-positive kava leaves. All ELISA tests were conducted according to manufacturer's instructions except for 25 of the triturated plant tissue samples used for IC RT-PCR reactions that gave positive results. These were ELISA tested as 'CEB' samples after storage at $-20^{\circ} \mathrm{C}$. The suitability of the manufacturer's recommended extraction buffer for detecting CMV in leaf material from plants other than those in which CMV had previously been successfully detected was ascertained in simple 'spiking' experiments. In these, desiccated positive control material was added to triturated healthy leaf samples, then positive results were obtained in ELISA tests.

\section{Mechanical inoculation of other plants using CMV from kava with dieback symptoms}

In three separate experiments conducted in an aphid proof shadehouse at the MASLR Koronivia Research Station in Fiji, ten typical kava intercrop plants plus two common weeds were artificially inoculated with CMV. The crop plants were banana cv. Sabah (cooking banana, ABB genotype) and cv. Grande Naine (Cavendish group, AAA genotype), pineapple, peanut, sweet potato, yam, papaya, taro (C. esculenta) and Xanthosoma sp. (the other common edible aroid known in Fiji as dalo ni tanna). All were local unnamed cultivars. The weeds were mile-a-minute (Mikania micrantha) and bitter gourd (Momordica charantia). The mechanical inoculation technique used was the same as that described in Davis et al. (1996). CMV was obtained from field-grown kava plants showing typical kava dieback symptoms by inoculating young Nicotiana tabacum seedlings (cv. PH09). Symptomatic N. tabacum leaves were then used as the inoculum source for mechanical transmission tests. Test plants were 1-2 months old when inoculated and all had tested negative for CMV by DAS-ELISA within 2 weeks prior to inoculation. Youngest available leaves of test plants were inoculated once in experiment 1 and twice in experiments 2 and 3 (second inoculation was 1 week later). Up to five replicate pots (some replicates were lost during the experiment) were used in each experiment and banana, mile-a-minute, taro and sweet potato were inoculated in two separate tests (experiments 2 and 3). All plants were tested again by DAS-ELISA, either when leaf symptoms were found (samples stored frozen from sampling until testing) or at the termination of each experiment, 6 weeks after inoculation. To determine if conditions were suitable for effective mechanical transmission, known susceptible plants [kava, tobacco or capsicum (Capsicum annuum)] were included in each experiment. For each potential host species tested at each inoculation time, an equal number of control plants was treated in an identical way, except that they were inoculated using only buffer rubbed on the leaf surfaces.

\section{Results}

\section{Intra plant $C M V$ distribution study}

CMV was detected in one third (33/99) of the tissue samples taken from infected kava plants (Table 1). Both detection methods (LS RT-PCR and IC RT-PCR) were suitable for all types of tissue samples, but IC RT-PCR appeared to be more sensitive (28\% samples positive compared with $12 \%$ with LS RT-PCR) (Table 1). The highest rate of CMV detection was from symptomatic leaves (10/12 positive results), followed by symptomless stems (8/17 positive results), roots and stem base samples (both $5 / 18$ positive results) and symptomless leaves $(5 / 34$ positive results) (Table 2).

Comparing the two groups of diseased plants (Table 2), over twice as many positive results $(26 / 48$ or $54 \%)$ were 
Table 1. Distribution of Cucumber mosaic virus in kava plants as determined by RT-PCR

\begin{tabular}{|c|c|c|c|c|}
\hline $\begin{array}{l}\text { Plant code } \\
\text { number }\end{array}$ & Sample type & $\begin{array}{l}\text { No. of samples LS } \\
\text { RT-PCR positive }\end{array}$ & $\begin{array}{l}\text { No. of samples IC } \\
\text { RT-PCR positive }\end{array}$ & $\begin{array}{c}\text { Total no. of } \\
\text { samples PCR } \\
\text { positive }\end{array}$ \\
\hline \multirow[t]{5}{*}{ LTI1 } & Leaves with symptoms & - & - & - \\
\hline & Symptomless leaves & $1 / 4$ & $0 / 4$ & $1 / 4$ \\
\hline & Symptomless stems & $1 / 3$ & $0 / 3$ & $1 / 3$ \\
\hline & Stem base & $0 / 3$ & $0 / 3$ & $0 / 3$ \\
\hline & Roots & $1 / 3$ & $0 / 3$ & $1 / 3$ \\
\hline \multirow[t]{5}{*}{ LTI2 } & Leaves with symptoms & - & - & - \\
\hline & Symptomless leaves & $1 / 10^{\mathrm{D}}$ & $0 / 10$ & $1 / 10$ \\
\hline & Symptomless stems & $0 / 3$ & $0 / 3$ & $0 / 3$ \\
\hline & Stem base & $0 / 3$ & $0 / 3$ & $0 / 3$ \\
\hline & Roots & $0 / 3$ & $0 / 3$ & $0 / 3$ \\
\hline \multirow[t]{5}{*}{ LTI3 } & Leaves with symptoms & $2 / 2$ & $2 / 2$ & $2 / 2$ \\
\hline & Symptomless leaves & $0 / 8$ & $1 / 8$ & $1 / 8$ \\
\hline & Symptomless stems & $0 / 3$ & $0 / 3$ & $0 / 3$ \\
\hline & Stem base & $0 / 3$ & $0 / 3$ & $0 / 3$ \\
\hline & Roots & $0 / 3$ & $0 / 3$ & $0 / 3$ \\
\hline \multirow[t]{5}{*}{ NI1 } & Leaves with symptoms & $5 / 5$ & $5 / 5$ & $5 / 5$ \\
\hline & Symptomless leaves & $0 / 5$ & $0 / 5$ & $0 / 5$ \\
\hline & Symptomless stems & $0 / 3$ & $2 / 3$ & $2 / 3$ \\
\hline & Stem base & $0 / 3$ & $0 / 3$ & $0 / 3$ \\
\hline & Roots & $0 / 3$ & $1 / 3$ & $1 / 3$ \\
\hline \multirow[t]{5}{*}{ NI2 } & Leaves with symptoms & $0 / 4$ & $3 / 4$ & $3 / 4$ \\
\hline & Symptomless leaves & $1 / 6$ & $1 / 6$ & $2 / 6$ \\
\hline & Symptomless stems & $0 / 3$ & $3 / 3$ & $3 / 3$ \\
\hline & Stem base & $0 / 3$ & $3 / 3$ & $3 / 3$ \\
\hline & Roots & $0 / 3$ & $3 / 3$ & $3 / 3$ \\
\hline \multirow[t]{5}{*}{ NI3 } & Leaves with symptoms & $0 / 1$ & $0 / 1$ & $0 / 1$ \\
\hline & Symptomless leaves & $0 / 1$ & $0 / 1$ & $0 / 1$ \\
\hline & Symptomless stems & $0 / 2$ & $2 / 2$ & $2 / 2$ \\
\hline & Stem base & $0 / 3$ & $2 / 3$ & $2 / 3$ \\
\hline & Roots & $0 / 3$ & $0 / 3$ & $0 / 3$ \\
\hline Total & & $12 / 99(12 \%)$ & $28 / 99(28 \%)$ & $33 / 99(33 \%)$ \\
\hline
\end{tabular}

${ }^{\mathrm{A}}$ LTI1, LTI2, LTI3 were plants known to be long-term CMV infected and were suffering ongoing dieback disease. NI1, NI2, NI3 were apparently new infections showing typical CMV-like yellow on green mosaic symptoms on one or more young leaves, but no advanced dieback-like stem rot symptoms.

${ }^{\mathrm{B}}$ Nucleic acids were extracted from plant tissues using the leaf soak method of

Thomson and Dietzgen (1995).

${ }^{\mathrm{C}}$ RT-PCR was conducted following immunocapture using Agdia compound direct ELISA reagent set antisera.

${ }^{\mathrm{D}}$ Active kava dieback lesion was visible on the stem from which this leaf was taken.

Table 2. Summary of Cucumber mosaic virus RT-PCR positive test results for within plant infection study

\begin{tabular}{lccc}
\hline Sample type & $\begin{array}{c}\text { Long-term infected } \\
(\mathrm{LTI})^{\mathrm{A}}\end{array}$ & $\begin{array}{c}\text { Newly infected } \\
(\mathrm{NI})^{\mathrm{B}}\end{array}$ & Total \\
\hline Leaves with symptoms & $2 / 2$ & $8 / 10$ & $10 / 12$ \\
Symptomless leaves & $3 / 22$ & $2 / 12$ & $5 / 34$ \\
Stem (no leaf symptoms) & $1 / 9$ & $7 / 8$ & $8 / 17$ \\
Stem base & $0 / 9$ & $5 / 9$ & $5 / 18$ \\
Roots & $1 / 9$ & $4 / 9$ & $5 / 18$ \\
Total & $7 / 51(14 \%)$ & $26 / 48(54 \%)$ & Chi square $=18.2^{\mathrm{C}}$
\end{tabular}

${ }^{A}$ LTI: plants known to be long-term CMV infected and were suffering ongoing dieback disease.

${ }^{B} \mathrm{NI}$ : plants apparently infected, showing typical CMV-like yellow on green mosaic symptoms on one or more young leaves, but no advanced dieback-like stem rot symptoms.

${ }^{\mathrm{C}}$ Significant at $P<0.01$. 
obtained from the recently infected plants compared with the long-term infections ( $7 / 51$ or $14 \%)$. A chi-squared value of 18.2 was calculated and this was significant at $P<0.01$. CMV was more prevalent in the more recently infected plants in parts of the plant other than those stems showing leaf symptoms. In these plants, CMV was found in most (7/8) of the samples from stems without leaf symptoms, and nearly half of the stem base and root samples (5/9 and $4 / 9$, respectively). In comparison, CMV was detected in the samples from long-term dieback plants in only $1 / 9$ samples of both stem and root, and was absent from stem base samples. The virus could not be detected by IC RT-PCR in any of the 39 tissue samples taken from the three symptomless control plants (data not included in Table 1).

Fourteen of the 25 triturated plant tissue samples that tested positive by IC RT-PCR were also positive by DAS-ELISA.

\section{Regrowth infection study}

Two of the 23 regrowth stems sampled from known CMVinfected kava plants $(9 \%)$ tested positive by IC RT-PCR (Table 3). In both cases, the stem, but not the leaf tissue, tested positive. One of these stems was from the NI3 (cv. Yaqona Loa), the other was from NI2 (cv. Yaqona Dokobana).

\section{Mechanical inoculation of other plants using CMV from kava with dieback symptoms}

CMV was successfully transmitted to both the dessert and cooking bananas, pineapple, peanut and mile-a-minute (Table 4). However, transmission rates were low (only one replicate of each of these plants tested positive following inoculation), compared with those of capsicum, tobacco and kava test plants, included as controls (four, five and six positive results, respectively, following inoculation). In this experiment, CMV was not successfully transmitted mechanically to taro, Xanthosoma sp., sweet potato, yam, papaya or $M$. charantia. Of the three inoculation attempts, the last one was the least successful (CMV was transmitted to one kava and one peanut plant only). This was the only

Table 3. Presence of Cucumber mosaic virus in new growth on naturally infected kava plants

\begin{tabular}{lccc}
\hline Plant & $\begin{array}{c}\text { No. stems } \\
\text { sampled }^{\mathrm{A}}\end{array}$ & $\begin{array}{c}\text { No. leaf samples } \\
\text { CMV-positive }^{\mathrm{B}}\end{array}$ & $\begin{array}{c}\text { No. stem samples } \\
\text { CMV-positive }^{\mathrm{B}}\end{array}$ \\
\hline NI1 & 10 & 0 & 0 \\
NI2 & 6 & 0 & 1 \\
Yaqona Loa 1 & 6 & 0 & 1 \\
Yaqona Loa 2 & 1 & 0 & 0 \\
Total & 23 & 0 & 2
\end{tabular}

\footnotetext{
${ }^{A}$ New young stems $(<20 \mathrm{~cm}$ in length) were sampled from kava plants more than 3 months after CMV infection had been confirmed by RT-PCR or DAS ELISA testing.

${ }^{B}$ Samples gave a positive IC RT-PCR result.
}

test of peanut, Xanthosoma sp. and yam as hosts, and also included the inoculation of a second set of five plants of taro and sweet potato.

\section{Discussion}

This study has demonstrated, using the greatly increased sensitivity of CMV detection possible with PCR compared with ELISA, that CMV is indeed not fully systemic in kava plants, as previously suggested by serological studies of Davis and Brown (1996) and Davis et al. (1996). The distribution of CMV in all diseased plants tested by RT-PCR was uneven and erratic, again in agreement with serological data from Tonga (Davis et al. 1996). Similarly, Hu et al. (1995) demonstrated that CMV distribution within banana plants also varies greatly.

CMV distribution in apparently recently infected plants that have yet to develop full dieback symptoms was more widespread than in plants with a long history of CMV infection and dieback. This may be due to host plant recovery determined by complex host-virus molecular interactions (Marathe et al. 2000). It may be that kava plants cannot very successfully limit systemic spread of CMV in early stages of dieback, and instead combat the virus by producing new growth that is infected at a very low rate. The results of the regrowth stem infection study reported here (new growth infection rate of only $9 \%$ ) as well as those of Davis et al. (1996) support this hypothesis. Following artificial inoculation experiments in Tonga, just over half of the new growth that followed death of CMV-infected stems was found by ELISA testing, to be free of CMV (Davis et al. 1996).

Table 4. Summary of three separate inoculation experiments

\begin{tabular}{lcc}
\hline & $\begin{array}{c}\text { CMV DAS-ELISA test } \\
\text { result }\end{array}$ \\
& after inoculation \\
\hline Control plants & - & - \\
Capsicum annuum & $4 / 5^{\mathrm{B}}$ & $1 / 5$ \\
Nicotiana tabacum & $5 / 5^{\mathrm{B}}$ & $0 / 5$ \\
Piper methysticum & $6 / 15^{\mathrm{B}}$ & $9 / 15$ \\
Test plants & & \\
Musa sp. cv. Sabah (ABB) & & \\
Musa sp. cv. Grande Naine (AAA) & $1 / 6$ & $5 / 6$ \\
Ananas comosus & $1 / 9^{\mathrm{B}}$ & $8 / 9$ \\
Arachis hypogaea & $1 / 5$ & $4 / 5$ \\
Mikania micrantha & $1 / 4$ & $3 / 4$ \\
Colocasia esculenta & $1 / 8$ & $7 / 8$ \\
Xanthosoma sp. & $0 / 10$ & $10 / 10$ \\
Ipomoea batatas & $0 / 5$ & $5 / 5$ \\
Dioscorea alata & $0 / 10$ & $10 / 10$ \\
Carica papaya & $0 / 5$ & $5 / 5$ \\
Momordica charantia & $0 / 5$ & $5 / 5$ \\
\hline
\end{tabular}

${ }^{\mathrm{A}}$ Tested using Agdia compound direct ELISA CMV reagent set, absorbance value (at $405 \mathrm{~nm}$ ) was $>$ three times the mean $(+)$, or $<$ three times the mean $(-)$ absorbance of a negative control leaf included on the test plate.

${ }^{\mathrm{B}}$ Leaves tested were showing virus-like symptoms. 
This higher rate of regrowth stem infection may reflect some differences in host-virus interactions following mechanical as opposed to natural infection.

Destruction of infected banana plants is a key component of the very successful Banana bunchy top virus (BBTV) phytosanitary strategy employed in eastern Australia (Dale and Harding 1998). An intensive banana plant rogueing regime in the Philippines has been shown to effectively reduce secondary spread of BBTV (Smith et al. 1998). Even greater success may be possible with kava dieback because the kavaCMV interaction appears to be similar to that of cassava and African cassava mosaic virus (ACMV). In both cases, lateral movement of virus from infected stems into other stems is restricted. Fargette and Vié (1995) suggested that incompletely systemic infection of cassava by ACMV was the principle reason for slow spread of ACMV within, and between, cassava crops.

In the case of kava, however, the high value of individual plants acts as a disincentive for growers to rogue out entire plants. Results of this study suggest effective disease suppression may be possible using a partially destructive rogueing policy (diseased stem removal). First, CMV was found most frequently in symptomatic kava leaves. CMV infection rates in leaves showing symptoms other than a yellow-on-green mosaic are lower and those in symptomless leaves are much lower (Davis et al. 1996). Constant removal of symptomatic leaves (with stem rogueing) would eliminate the most significant inoculum source for plant-to-plant spread by aphids. Second, new growth was found to be largely disease-free, suggesting a chance of recovery in these carefully pruned plants. However, for this to work, the kava grower would have to be extremely vigilant. As the virus may be present in other apparently healthy looking stems at any time that a diseased stem is removed, the grower must return frequently to remove more stems as they, in turn, develop leaf symptoms.

This study provides some preliminary data on host range, following mechanical inoculation, of a kava diebackinducing strain of CMV from Fiji. CMV strain host range can depend on which subgroup it falls into (Carrère et al. 1999). Investigations into the diversity of this and other strains of CMV causing kava dieback in Fiji and elsewhere have commenced recently. Sequence analyses of coat protein-coding regions of this CMV RNA showed closest alignment with reference strains from subgroup I of CMV (M. Dickinson, University of Nottingham, UK, personal communication).

Reductions in spread of CMV within plots of kava should be achieved by using non-host intercrops because many viruliferous aphids moving between kava plants would lose their transmissibility after brief probes on non-hosts. This study has identified taro, Xanthosoma sp., sweet potato, papaya and yam as possibly useful intercrops for further investigation. The third inoculation test was conducted during the warmer months of the year and transmission rates were low. CMV symptom expression in a number of hosts is known to be reduced in summer compared with winter conditions in south-east Queensland, Australia (Sulistyowati et al. 2004). It is not known if non-transmission to test plants (especially Xanthosoma sp. and yam, inoculated only once in the third batch of plants) was due to host factors or because test conditions were unsuitable. Mechanical inoculation test results with a given plant species may not be indicative of its importance as a host in the field. It may be that vector feeding preferences and probing behaviour (Kennedy et al. 1959) have greatest influence. Experiments to determine if kava dieback inducing strains of CMV can be transmitted by aphids to these potential intercrops are needed. Aphis gossypii is known to transmit CMV between kava plants (Davis et al. 1996) but other aphids should also be investigated as CMV transmission can depend on aphid species and virus strain (Perry et al. 1995). A comprehensive program of CMV screening of symptomatic and symptomless leaf samples collected from these intercrops growing in known kava dieback disease 'hot spots' of infection is also necessary before making recommendations to kava growers. This study is now in progress across several locations in Fiji, and vector experiments are planned.

Symptomless infection of mile-a-minute is a significant new record. M. micrantha is not included in known CMV host listings (Douine et al. 1979; CABI 2002) and the importance of this extremely common weed in Fiji as a host of CMV needs to be determined. CMV screening of numerous $M$. micrantha leaf samples is in progress as outlined above for kava intercrops. M. micrantha is an aggressive perennial vine, often poorly, or not at all, controlled by farmers in the Pacific (W. Orapa, Weed Management Coordinator, SPC, personal communication). If it proves to be a significant CMV reservoir, long-term control strategies (such as the introduction of biocontrol agents) may be of value to kava growers in those Pacific Islands where this weed occurs.

Formal field and farmer participatory trials are now being conducted in Fiji and Tonga to measure the effectiveness of diseased stem rogueing. Stems are broken off (not cut with a knife as CMV is sap transmissible) and placed in an insect proof bag prior to removal and destruction (to also eliminate viruliferous aphids if present). These trials may prove that rogueing out infected stems as soon as they are found can be a useful component in an integrated kava dieback control strategy. However, it has been demonstrated for other virus diseases that rogueing alone is not always enough. Examples include the somewhat similar ACMVcassava pathosystem; when inoculum pressure was high and when much secondary spread occurred, stringent rogueing programmes failed (Thresh et al. 1998). Smith et al. (1998) concluded that in the presence of numerous external BBTV inoculum sources, rogueing was not effective for banana 
bunchy top control. In the case of kava and CMV, advantage can be taken of the non-persistent nature of the virus and this can be combined with natural benefits of traditional Pacific Island farming systems to combat these factors. In traditional kava cultivation, the crop is grown on carefully chosen (well drained and fertile) soils in small isolated plantings, with several different intercrops and below a tree canopy. The principle observation made on extensive kava dieback disease surveys throughout Fiji, Vanuatu, Tonga and Samoa is that epidemics reach greatest proportions in large monocultures on almost totally cleared land and are often minor or non-existent in such traditional plantings (R. Davis and J. Brown, unpublished data). Intercropping only with non-hosts or occasional CMV hosts should effectively reduce within-plot CMV movement and external inoculum arriving with incoming alate aphids should be decreased if kava is cultivated below a tree canopy because most trees are not known to be hosts of CMV. These advantages would not be applicable in the case of persistently transmitted ACMV and BBTV and (unlike banana and cassava) kava grows better under shade (Davis and Brown 1999). Exclusive use of only disease-free planting material would also be an essential component of a good integrated disease management strategy.

\section{Acknowledgements}

This work was funded by the European Union through the SPC's Plant Protection in the Pacific project. Dr B. Aalbersberg of the University of the South Pacific's Institute of Applied Science, Suva, Fiji Islands, is gratefully thanked for allowing use of a molecular diagnostics laboratory to analyse samples. We gratefully acknowledge the help and facilities provided by the Director (Mr J. Kumar) and staff of the Fiji Ministry of Agriculture, Sugar and Land Resettlement's Koronivia Research Station.

\section{References}

Anon. (2001) 'Pacific kava a producer's guide.' (Secretariat of the Pacific Community: Fiji)

Anon. (2003) Kava dieback disease. Plant Protection Service, Secretariat of the Pacific Community, Farmer Advisory Leaflet No. 1, Fiji.

Bariana HS, Shannon AL, Chu PWG, Waterhouse PM (1994) Detection of five seedborne legume viruses in one sensitive multiplex polymerase chain reaction test. Phytopathology 84, 1201-1205.

Bos L, Maat DZ (1974) A strain of cucumber mosaic virus, seed-transmitted in beans. Netherlands Journal of Plant Pathology 80, 113-123.

Brunt AA, Jackson GVH, Frison EA (Eds) (1989) 'FAO/IBPGR technical guidelines for the safe movement of yam germplasm.' (Food and Agriculture Organisation of the United Nations, Rome/International Board for Plant Genetic Resources: Rome)

CABI (2002) 'Crop protection compendium.' (CAB International: Wallingford, UK)
Carrère I, Tepfer M, Jacquemond M (1999) Recombinants of cucumber mosaic virus (CMV): determinants of host range and symptomatology. Archives of Virology 144, 365-379. doi: $10.1007 / \mathrm{s} 007050050510$

Dale JL, Harding RM (1998) Banana bunchy top disease: current and future strategies for control. In 'Plant virus disease control'. (Eds A Hadidi, RK Khetarpal, H Koganazawa) pp. 659-669. (APS Press: St Paul, USA)

Davis RI (1999) Kava dieback. Secretariat of the Pacific Community Pest Advisory Leaflet No. 25, Fiji.

Davis RI, Brown JF (1996) Epidemiology and management of kava dieback caused by cucumber mosaic cucumovirus. Plant Disease 80, 917-921.

Davis RI, Brown JF (1999) Kava (Piper methysticum) in the South Pacific: its importance, methods of cultivation, cultivars, diseases and pests. Australian Centre for International Agricultural Research Technical Report No. 46, Canberra.

Davis RI, Brown JF, Pone SP (1996) Causal relationship between cucumber mosaic cucumovirus and kava dieback in the South Pacific. Plant Disease 80, 194-198.

Douine L, Quitot JB, Marchoux G, Archange P (1979) Recensement des espèces végétales sensibles au Virus de la Mosaïque du Concombre (CMV) Etude bibliographique. Annales de Phytopathologie 11, 439-475.

Egan BT, Ryan CC, Francki RIB (1989) Fiji disease. In 'Diseases of sugarcane major diseases'. (Eds C Ricaud, BT Egan, AG Gillespie, CG Hughes) pp. 263-288. (Elsevier: Amsterdam)

Fargette D, Vié K (1995) Simulation of the effects of host resistance, reversion, and cutting selection on yield losses in cassava. Phytopathology 85, 370-375.

Frison EA, Bos L, Hamilton RI, Mathur SB, Taylor JD (Eds) (1990) 'FAO/IBPGR technical guidelines for the safe movement of legume germplasm.' (Food and Agriculture Organisation of the United Nations, Rome/International Board for Plant Genetic Resources: Rome)

Garnsey SM, Gottwald TR, Yokomi RK (1998) Control strategies for Citrus tristeza virus. In 'Plant virus disease control'. (Eds A Hadidi, RK Khetarpal, H Koganazawa) pp. 639-658. (APS Press: St Paul, USA)

Gatty R (1956) Kava-Polynesian beverage shrub. Economic Botany 10, 241-249.

Hu JS, Li HP, Barry K, Wang M, Jordan R (1995) Comparison of dot blot, ELISA, and RT-PCR assays for detection of two cucumber mosaic virus isolates infecting banana in Hawaii. Plant Disease 79, 902-906.

Kegler H, Hartmann W (1998) Present status of controlling conventional strains of Plum pox virus. In 'Plant virus disease control'. (Eds A Hadidi, RK Khetarpal, H Koganazawa) pp. 616-629. (APS Press: St Paul, USA)

Kennedy JS, Booth CO, Kershaw JS (1959) Host finding by aphids in the field. II. Aphis fabae Scop. (Gynoparae) and Brevicoryne brassicae L.; with a re-appraisal of the role of hostfinding behaviour in virus spread. Annals of Applied Biology 47, 424-444.

Kumar S, Kaitetara T, Mudaliar T (1998) 'Opportunities for the production of yaqona in Fiji for export. Situation analysis No. 1.' (Ministry of Agriculture, Forestry and Fisheries and Soil Evaluation Project: Fiji)

Lebot V, Merlin M, Lindstrom M (1992) 'Kava the Pacific drug.' (Yale University Press: Newhaven)

Marathe R, Anandalakshmi R, Smith TH, Pruss GJ, Vance VB (2000) RNA viruses as inducers, suppressors and targets of post-transcriptional gene silencing. Plant Molecular Biology 43, 295-306. doi: 10.1023/A:1006456000564 
Parham BEV (1935) Wilt disease of 'yangona'. Fiji Agricultural Journal 8, 2-8.

Perry KL, Zhang L, Palukaitis P (1995) Differential transmission of cucumber mosaic virus by two aphids: mutations in the coat protein restore transmission by Aphis gossypii but not by Myzus persicae. Phytopathology 85, 1143.

Roossinck MJ (2001) Cucumber mosaic virus, a model for RNA virus evolution. Molecular Plant Pathology 2, 59-63. doi: 10.1046/j.1364-3703.2001.00058.x

Sharman M, Thomas JE, Dietzgen RG (2000) Development of a multiplex immunocapture PCR with colourimetric detection for viruses of banana. Journal of Virological Methods 89, 75-80. doi: 10.1016/S0166-0934(00)00204-4

Singh YN (1992) Kava: an overview. Journal of Ethnopharmacology 37, 13-45. doi: 10.1016/0378-8741(92)90003-A

Singh Z, Jones RAC, Jones MGK (1995) Identification of cucumber mosaic virus subgroup I isolates from banana plants affected by infectious chlorosis disease using RT-PCR. Plant Disease 79, 713-716.
Smith MC, Holt J, Kenyon L, Foot C (1998) Quantitative epidemiology of Banana bunchy top virus disease and its control. Plant Pathology 47, 177-187.

Sulistyowati E, Mitter N, Bastiaan-Net S, Roosinck MJ, Dietzgen RG (2004) Host range, symptom expression and RNA 3 sequence analyses of six Australian strains of Cucumber mosaic virus. Australasian Plant Pathology 33, 505-512. doi: 10.1071/AP04054

Thomson D, Dietzgen RG (1995) Detection of DNA and RNA plant viruses by PCR and RT-PCR using a rapid virus release protocol without tissue homogenization. Journal of Virological Methods 54, 85-95. doi: 10.1016/0166-0934(95)00022-M

Thresh JM, Otim-Nape GW, Fargette D (1998) The control of African cassava mosaic disease: phytosanitation and/or resistance? In 'Plant virus disease control'. (Eds A Hadidi, RK Khetarpal, H Koganazawa) pp. 670-677. (APS Press: St Paul, USA)

Received 25 February 2005, accepted 20 April 2005 